\title{
Business English Translation Education Innovation Practice Based on School Enterprise Cooperation Personnel Training Program
}

\author{
ZouWeiwei \\ Nanchang Institute of Science \&Technology, Nanchang 330108, China
}

\begin{abstract}
Keywords: Multi objective optimization, English translation, School enterprise cooperation, Globalization, Optimal solution.
\end{abstract}

\begin{abstract}
With the continuous expansion of economic globalization trend, our country for business translation talent gap is also growing, the education ministry firstly set up the first business English major at International Business and Economics University, from now on business English translation courses become an important part of English teaching. English course is an important professional course in Business English, people should be integrated into the translation practice and practice environment in the course of the curriculum, which mainly include advertising translation, letter translation, contract translation, professional translation, etc.. In order to realize the reasonable allocation of the course content, this paper proposes a multi-objective optimization allocation method, and the optimal solution can be as the standard, which can get a reasonable course configuration through the target optimization and continuous correction.
\end{abstract}

\section{Introduction}

Business English translation is an important business English major, the training of the professional talents need to consider the basic theory knowledge of business English and the knowledge and skills of business field, improving students' practical ability and professional quality $[1,2]$. In the past three years, the statistics found that the proportion of practical link in business English translation teaching curriculum is not high, therefore, it is necessary to set up the course of the reasonable improvement [3-5]. Combined with the training program of enterprise cooperation, the construction of English translation course is discussed and studied by using the translation training platform of enterprises investment and construction in school, which has important significance for the further expansion of school enterprise cooperation.

\section{Business English Translation Teaching Practice Based on School Enterprise Cooperation Training Program}

Business English translation major is a strong application of professional, so people should be fully considered the combination of business English and business training project in the course of the curriculum, and combined with the actual situation of the school, this paper explores the school productive training program.

Training project background. The core course of business English major is English translation, which is a practical and comprehensive course. The specific performance of students' learning characteristics and background is [6-8]:

(1) Translation is the most common task for business English majors, so students must master some translation skills and translation experience;

(2) The training of translation skills and the accumulation of the translation experience depend on the daily work, which is not enough to learn from the theory of the classroom. Therefore, the schools need to provide a practical training platform for students;

(3) There is capital investment and support from outside trading company;

(4) The globalization of economy makes business English translation have a great potential market, and the e school competitiveness is often smaller than the translation business in small and medium cities; 
(5) School teachers have the translation experience and language skills, and they have the ability to lead the students to complete the translation project of the company;

(6) Students' ability training should be combined with the market actual needs, which will be welcomed by the market and students.

\section{Project implementation.}

(1)The establishment of the comprehensive translation training room

The comprehensive translation training room is invested and constructed by outside trading company, in which hardware equipment includes 8 computer hosts, 2 switches, 1 teaching projectors, 1 translation desk and 80 chairs. All kinds of dictionaries have 4 sets, and software includes English translation software and operating system, providing the teaching and practice platform of a set of business English and application English for students.

(2) Translation practice training project

The project design and expansion is mainly for business English major sophomore students, which designs the independent business English translation program, and students carry out training in the comprehensive training room, training time is two weeks, hours is 60 hours, students will be tested after training. According to the true employment of graduates tracking and investigation, this paper selects several and related work to carry out the targeted translation practice and training, including advertising translation, letter translation, contract translation, professional translation, etc.. In the course of training, teachers carry out some of the targeted explanations for the translation skills and methods, and carries on the critique combined with the practice of students, supplying the lack of students' translation skills and methods.

(3) The establishment of business English translation studio

Through teachers and students for the enterprise to carry out the practice of translation, we create a school translation studio, to further improve the students' translation practice. The studio is open to the outside world, the students are guided by the teacher to complete the translation task, and they can undertake a large number of English translation tasks based on the trading company. Students can be divided into different groups according to the need, such as the company profile group, contract project group, business letters group, integrated translation group, etc., a higher translation level of students as head [9-11]. First, the teacher will give the translation of the enterprise to the students, the translation practices are early finished by the group members, and then to revise by the group leader and senior students, finally the teacher and industry consultants carry out check. Through the cooperation between enterprises and school, it can effectively reduce the students' capital investment, improving their professional ability, exercising the students' translation level and improving their future job responsibility and self-confidence.

\section{Business English Translation Course Orientation and Teaching Objective Optimization}

In the course of business English translation, we should take into account the specific translation practice and training, including advertising translation, letter translation, contract translation and professional translation as a teaching objective, they can be shown in $\left(f_{1}, f_{2}, \ldots, f_{p}{ }^{*}\right)$. However, in the course of setting up the course, the setting and distribution of these courses $f_{i} *(i=1,2, \ldots, p)$ cannot achieve the best, so we can find an optimal solution. To the optimal solution as the standard, the target value is modified by the target optimization principle, the constraint conditions are calculated, and finally the target is optimized, to achieve a rational allocation of course.

First of all, according to the $p$ single objective problem of the advertising translation, letter translation, contract translation and professional translation, this paper solve the problem of the optimal solution, the expression is

$$
\max f_{i}(X)=\sum_{j=1}^{n} c_{i j} x_{j} .
$$


In which, $x_{j}$ represents each content of setting curriculum, and $c_{i j}$ shows the ratio of setting course. Through the calculation, we can obtain the optimal solution $X^{i^{*}}(i=1,2 \ldots, p)$, and the corresponding curriculum setting target value is $f^{i^{*}}(i=1,2 \ldots, p)$. In the optimal goal, taking the value of the course content is $z_{k i}, z_{k i}=f_{k}\left(X^{i^{*}}\right), k \neq i, k=1,2, \ldots, p$, and then through the multi objective optimization, we can obtain

$$
\begin{array}{ccccccc}
X & f_{1} & f_{2} & \cdots & f_{i} & \cdots & f_{p} \\
X^{1^{*}} & f_{1} * & z_{21} & \cdots & z_{i 1} & \cdots & z_{p 1} \\
\vdots & \vdots & \vdots & \vdots & \vdots & \vdots & \vdots \\
X^{i^{*}} & z_{i 1} & z_{i 2} & \cdots & f_{i} * & \cdots & z_{p i} \\
\vdots & \vdots & \vdots & \vdots & \vdots & \vdots & \vdots \\
X^{p^{*}} & z_{1 p} & z_{2 p} & \cdots & z_{i p} & \cdots & f_{p}{ }^{*}
\end{array}
$$

Taking the minimum value of each column is the minimum value $f_{i p}(i=1,2, \ldots p)$ for $i$-th column, then we solve

$\min \lambda$

$\left\{\begin{array}{l}\pi_{i}\left(f_{i}^{*}-f_{i}(X)\right) \leq \lambda, \quad i=1,2, \ldots, p \\ X \in S \\ \lambda \geq 0\end{array}\right.$.

Among then,

$$
\begin{aligned}
\pi_{i} & =\frac{\alpha_{i}}{\sum_{i=1}^{p} \alpha_{i}} . \\
\alpha_{i} & =\left\{\begin{array}{l}
\frac{f_{i} *-f_{i}^{p}}{f_{i}^{*}}\left(\sum_{j=1}^{n} c_{i j}{ }^{2}\right)^{-1 / 2}, f_{i}^{*}>0 \\
\frac{f_{i}^{p}-f_{i} *}{f_{i}^{p}}\left(\sum_{j=1}^{n}{c_{i j}}^{2}\right)^{-1 / 2}, f_{i}^{*} \leq 0
\end{array}\right.
\end{aligned}
$$

When the content setting of the course is less than the $\Delta f_{j}$ value of the $j$-th target, the corresponding constraint conditions will be changed as shown in formula (6).

$$
S^{*}=\left\{\begin{array}{l}
S \\
f_{j}(X) \geq f_{j}\left(X_{0}\right)-\Delta f_{j}, j=1,2, \ldots, k . \\
f_{i}(X) \geq f_{i}\left(X_{0}\right), i \neq j, i=1,2, \ldots, p
\end{array}\right.
$$

In the further iteration, the target function $f_{j}(j=1,2, \ldots, k)$ is reduced, and the weight coefficient can be taken as 0 , namely $\pi_{i}$ should be set to 0 . By continuous iteration, the ratio of the best course project settings is obtained.

\section{The Settings of English Translation Curriculum Based on School Enterprise Cooperation}

Business English translation is a strong professional and practical course, but in the past three years, the school is not enough attention to the practice class, and the direction of the profession is not 
obvious [11,12]. Table 1 statistics the proportion of business English translation practice course for the past three years.

Table 1. The proportion of business English translation practice course in recent three years

\begin{tabular}{|c|c|c|c|}
\hline Time & $\begin{array}{c}\text { Theory teaching class } \\
\text { hours }\end{array}$ & Practice class hours & The percentage of total class hours \\
\hline 2013 & 200 & 10 & $5.00 \%$ \\
\hline 2014 & 220 & 12 & $5.45 \%$ \\
\hline 2015 & 230 & 12 & $5.22 \%$ \\
\hline
\end{tabular}

Table 1 shows the proportion of business English translation practice course in the past three years, it can be seen that the proportion of the practice course total class hours is not high. Through the previous training program, it can be seen that for training students' professional ability, practical links has an important influence on improving the translation level, therefore this paper needs to set up the course to do further improvement, the principle is shown in Figure 1.

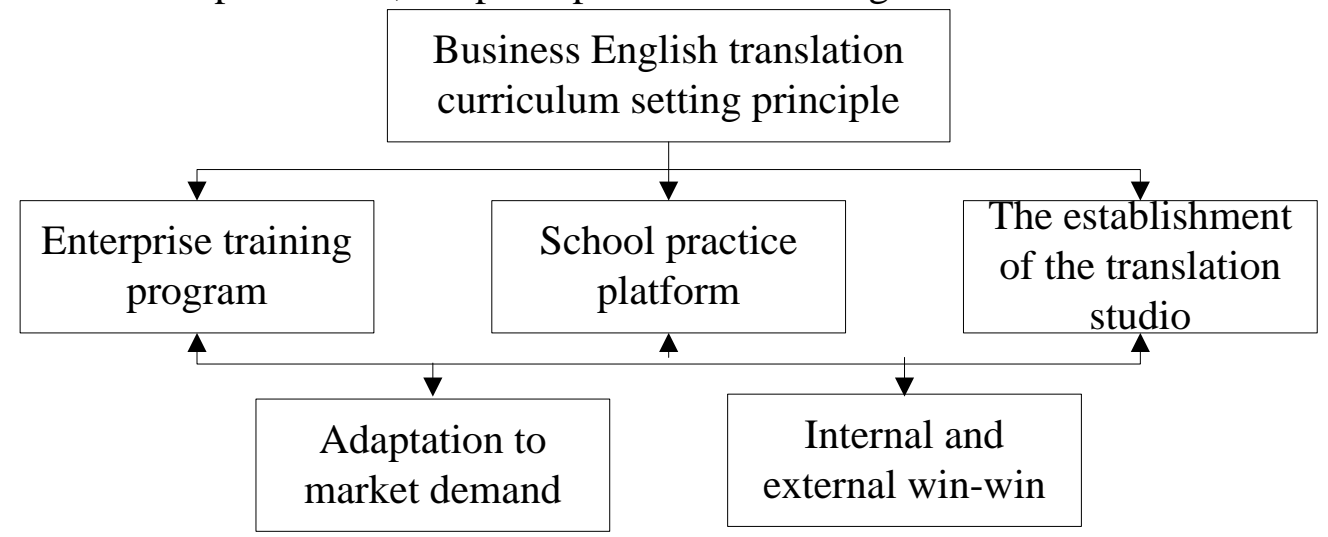

Fig. 2 The setting principle of business English translation course

Figure 2 shows the principles of setting up the business English curriculum based on the enterprise training program, the principle is to cultivate applied talents as the main principle. Through the enterprise in the school training program, it can improve the market adaptability of the school curriculum content; through the enterprise in the school to set up translation practice platform and the school's human resources investment, people establishes translation studio to achieve the school enterprise win-win. According to the multi-objective optimization model proposed by the second part of this paper, the contents of the curriculum practice are determined by the principles of business English translation course as shown in Table 2.

Table 2. The optimization distribution ratio of business English translation course

\begin{tabular}{|l|c|c|}
\hline Translation course content & $\begin{array}{c}\text { Account for the proportion of } \\
\text { specialized courses }\end{array}$ & $\begin{array}{c}\text { Account for total class } \\
\text { hours }\end{array}$ \\
\hline Advertisement translation & $33 \%$ & $12.1 \%$ \\
\hline Letter translation & $37 \%$ & $18.2 \%$ \\
\hline Contract translation & $18 \%$ & $9.3 \%$ \\
\hline Professional document translation & $12 \%$ & $7.8 \%$ \\
\hline
\end{tabular}

Table 2 shows the several optimized allocation ratio of the final determining practical courses and business English courses, it can be seen that the proportion of the practice training link is obviously improved, the content of the translation courses have also been optimized allocation.

\section{Summary}

This paper explores the business English translation practical project of school enterprise cooperation development, which builds a social and enterprises practical platform for students 
through the implementation of the project. Through the project practice, it proved that the implementation of the project can effectively improve students' translation ability and level, improving the employment confidence and job responsibility, which provides valuable experience in order to further expand the school enterprise cooperation project. Enterprises can spend less money and do more work, and the school can also be less investment, so students' practical ability and professional ability can be substantial improved, to achieve a win-win situation between enterprises and schools, this method can be promoted in other colleges and universities.

\section{References}

[1] Q. Guan. Cross language learning psychological assessment- Evidence from Chinese and English reading motivation and reading level. Foreign language teaching theory and practice, 2013(1): 14-18.

[2] Z.J. Qin, J.Y. Li. research on second language reading strategies: review and prospect in 30 years. Foreign language teaching, 2014(4): 43-49

[3] Q.L. Wu, J.C Luo., H.M. Yang. Study on the metacognitive awareness of English major students in English reading strategies. Journal of East China University of Science and Technology, 2013 (4): 105-116.

[4] L.P. Pan. An empirical study on ESL reading metacognitive strategy awareness on the effect of reading. Journal of Hangzhou Normal University, 2013(2): 118- 122.

[5] J.Y. Wang, B.S. Jiang. The overall trend and macro reading strategies. Journal of Xi'an Foreign Languages College, 2013(4): 60-63.

[6] X.M. Zeng. The reading ability of improving English major students through training extracurricular reading metacognitive strategy. Liberation Journal of PLA University, 2013(6): 60-66.

[7] X.H. Jiang. Thinking about the compound English talents cultivation mode. Heilongjiang high education research, 2014(3): 137-138.

[8] X.Y. Fan. Analysis of the business English subject orientation. Continuing education research, 2014(10): 12-15.

[9] B.Y. Pan. The establishment of the higher vocational education independent system. Education research, 2014(5): 13-16.

[10] Y. Wu. The requirements analysis of English major business English course. Journal of Chongqing University, 2013(6): 22-28.

[11] Z.M. Chen. Interpretation of the business English major undergraduate course teaching requirements in higher school. Chinese language, 2013(4): 33-39.

[12] W.L. Tong, X.B. Xian. New thinking on the business English subject orientation. High school education exploration, 2013(6): 28-32. 